\title{
Impact of Demographic Processes on the Labor Market of Uzbekistan
}

\author{
Abdurakhmanov Kalandar Khodzhaevich, Umurzakov Bahodir Khamidovich, Zokirova Nodira \\ Kalandarovna, Tula Nodirbek Bakhodir ugli, Abdurakhmanova Gulnora Kalandarovna
}

\begin{abstract}
The article is devoted to the problems and priority areas in the management of economic risks in the field of communication and information in the formation of the information society in Uzbekistan. At the current stage of market relations, the quality of organizations and enterprises is directly proportional to the effective implementation of information technologies. With the intensive development of information technologies, the volume of data exchange significantly increases, which leads to new problems in production management. High competition in the market of information technologies contributes to the emergence of specific risks that are important for innovative sectors of the economy. The key point in risk management in the information and communication sphere is its assessment. In our view, these estimates have quantitative and qualitative characteristics. The essence of the proposed risk management scheme in this article is that the main objective of risk management is to organize regular monitoring of risks associated with risks and risk indicators, rather than insurance and risk forecasting. The content of risk indicators is that when elements of an economic entity slip into the risk side, they begin to give certain signals. Risk indicators are the set of aggregate economic indicators which allow monitoring of the local manifestation of various risks and, if necessary, respond properly to certain risks in order to achieve the desired results. Based on signals from risk indicators, a risk assessment methodology is revealed which includes synthetic, qualitative and quantitative assessment. The concluding part of this article contains several proposals on how to manage risks in the field of info-communication and information in the formation of the information society.
\end{abstract}

The main conclusions of the article can be used as a theoretical, methodological and practical basis in the enterprises

Revised Manuscript Received on October 15, 2019.

* Correspondence Author

Abdurakhmanov Kalandar Khodzhaevich, Academician of the Academy of Sciences of the Republic of Uzbekistan, Doctor of Economics, Professor, Director of the Tashkent Branch of the Russian Economic University. G.V. Plekhanov Republic of Uzbekistan, 100003, Tashkent Islam Karimov, 49, building 7, KAbdurakhmanov@yandex.ru Тел.:+99890 1855707

Umurzakov Bahodir Khamidovich, Doctor of Economics, Professor, Deputy Minister of Employment and Labor Relations of the Republic of Uzbekistan, Republic of Uzbekistan, 100100, Tashkent city, Mirabad district, st. Mirabad, 15, info@mehnat.uz (0-371) 239-12-72

Zokirova Nodira Kalandarovna ,Doctor of Economics, Professor, Head of the Department of the Tashkent Branch of the Russian Economic University. G.V. Plekhanov, Republic of Uzbekistan, 100003, Tashkent Islam Karimov, 49, building 7, nodira28uz@mail.ru Тел.: +99890 3205050 Tula Nodirbek Bakhodir ugli, Senior lecturer of the Tashkent Branch of the Russian Economic University, Republic of Uzbekistan, 100003, Tashkent Islam Karimov, 49, building 7 nodir_bek1990@mail.ru Тел.:+998909559559

Abdurakhmanova Gulnora Kalandarovna ,Doctor of Economics, Professor. Head Department of Tashkent State University of Economics Republic of Uzbekistan, 100003, Tashkent Islam Karimov, 49, building 7, KAbdurakhmanov@yandex.ru +998909555050

of information and communication sphere, as well as in other spheres.

Keywords : information and communication technologies, risk management of information and communication system, quantitative assessment, risk indicators, market economy, information society, state regulation, evaluation of the effectiveness of the risk management system at the macroeconomic level, synergetic effect, balance liquidity analysis.

\section{INTRODUCTION}

The relevance of the study is confirmed by the fact that in the world, on the basis of statistical data and their analysis, important decisions are made on planning the creation of new jobs, infrastructure, construction, number of educational and medical institutions. But in practice, economic and statistical studies have paid little attention to the relationship between demographic processes and the labor market. The labor market is a dynamic system that includes a set of social and labor relations about the conditions of employment, use and exchange of labor for life, and the mechanism of supply and demand, operating on the basis of information received in the form of changes in the price of labor (wages) (Labor Market, 2003).

The aim of the study is to analyze the demographic factors affecting the supply in the labor market over time. In order to conduct a comprehensive study in Uzbekistan, a detailed study of all demographic factors is necessary, as well as their impact on the labor market and population employment.

In Uzbekistan, the provision of employment has always been one of the most important social problems. The government of Uzbekistan also understands the importance of solving problems arising in the labor market. President of the Republic of Uzbekistan Sh.M. Mirziyoev in his message to the Parliament noted: "Economic development and social protection are inseparable concepts ... it is necessary to reduce the unemployment rate among the population, increase the incomes of people and families." (Sh.M Mirziyoyev, 2018). This indicates that the problem of improving the labor market is discussed at the highest level. When analyzing the labor market, it is necessary to take into account legal acts. In accordance with the Law on Employment: "Citizens of the Republic of Uzbekistan have the exclusive right to manage their abilities for productive and creative work and to carry out any activity not prohibited by law, including work related to paid work" (Employment Law, 1998). 
Administrative coercion to work in any form is not allowed, with the exception of cases established by the legislation of the Republic of Uzbekistan. Voluntary unemployment of people can not serve as a basis for bringing them to justice. In collaboration with the International Labor Organization, effective measures have been taken to eradicate child and forced labor (Sh. M. Mirziyoyev, 2017).

From a scientific point of view, it is advisable to consider the "demographic processes" and "labor market" separately. With the introduction of the category "labor market" into scientific use, many economists, demographers, statisticians and other representatives of science began to use this term in various interpretations (Abdurakhmanov K., et al. 2013) (Odegov Yu.G. et al 2014) (Abdurakhmanov K X, 2018).

According to the definition of E.A. Kechina, the "demographic process" is a sequence of similar events in the life of people that is important for the change of their generations (Steshenko V.S., 2014). We believe these definitions have a right to exist, but at the same time we propose to use a more concise interpretation for the definition of the notion "demographic process": The demographic process is a mechanical (migration) or natural (fertility, mortality, marriage and divorce) movement of the population. For the practical application of demographic processes, it is necessary to consider their main indicators of development. One of the most important of these indicators is the total fertility rate.

The total fertility rate is the most accurate indicator of the birth rate, this coefficient characterizes the average number of births for one woman in the hypothetical generation for her entire life while maintaining the existing levels of fertility at each age, regardless of mortality and changes in the age composition (Population, 1995). Changes in fertility are important for determining the process of developmental dynamics and the effect on the age structure of the population (Ewa Zofia Frątczak, 2013). This coefficient is calculated as the sum of specific fertility rates in a particular year (Roland Pressat, 1978).

According to N. Volgin: "The labor market expresses the deepest essence of commodity-money, social and labor relations about the conditions of employment and use of workers in social production: these are relations of exchange of functioning labor (labor) for means of subsistence, real wages for the basis of the laws of supply and demand, labor costs, marginal productivity of labor and competition (Labor Market and Incomes, 1999).

"Labor market" is a sphere of contacts between sellers and buyers of labor services, as a result of which the price level and distribution of labor services are established (Nikolaeva I.N., 2006).

Zemyanukhina S.G. believes that the labor market acts as a specific form of the exchange phase in the system of human resources reproduction, when the human resources formed during their production (which have already become labor resources) enter the market in order to connect with the means of production (Zemyanukhina SG, 2004).

According to the definition of A.V. Kashepova, the labor market is a sphere in which each other is opposed, on the one hand, job seekers, including the unemployed, on the other, employers who have unoccupied jobs in enterprises, organizations that have labor contracts between them, are defined salary level (Kashepov A.V. et al., 2008). This definition is rather narrow and does not fully reflect the socio-economic relations in the labor market.

There are also interpretations of the labor market, as a system of "socio-economic and labor relations, within the framework of social peace and harmony that arise between employers and employees with the participation of state and public organizations, on the basis of supply and demand, about pay and working conditions, social guarantees, social protection and support, etc. "(Labor Economics, 2002).

According to M.A. Vinokurova: "The labor market is a system of economic relations that are shaped by the formation, consumption, distribution and redistribution of labor, its hiring and payment, regulated by legal norms and manifested as a resource management method" (Vinokurov, MA, 1981). This definition is rather voluminous, but reflects the essence of the labor market is not accurate enough.

A more detailed concept of "Labor Market" is given by the economist A.I. Rofe: "The labor market is a system of economic relations connected with the hiring and supply of labor, i.e. with its purchase and sale; it is also an economic and geographical space - the sphere of employment, in which buyers and sellers of a specific product of labor interact; Finally, it is a mechanism that ensures the coordination of price and working conditions between employers and employees "(Rofe AI, 2016).

The most specific definition is given by academician Abdurakhmanov K.Kh. "The labor market is a special subsystem of a market economy in which employers (owners of means of production) interact, on the one hand, and hired employees on the other. As a result of these relationships in the labor market, the volume, structure, and the ratio of supply and demand for labor are formed "(Economic Theory, 1999), (Abdurakhmanova G. et al., 2018).

In accordance with the purpose of the study, we formulate the following definition of the labor market. The labor market is a place (enterprise, organization, etc.) where a balance of supply and demand is reached, and there is agreement between employers and employees about the cost of labor, social support and guarantees (pay and working conditions).

\section{MATERIALS AND METHODS}

In the study of problems using the methods of grouping, correlation and regression analysis, rank correlation.

We have grouped the population by age, dividing the population into three groups younger than working age (up to 16 years old), working age (16-55 for women, 16-60 for men). For the analysis of structural changes, an analysis is carried out for the years 1991-2017 grouped in five-year periods.

Correlation-regression method contains two of its constituent parts - correlation analysis and regression analysis. Correlation analysis is a quantitative method for determining the closeness and direction of the relationship between sampling variables. Regression analysis is a quantitative method for determining the type of mathematical function in a causal relationship between variables.

To study the relationships and interdependencies, not only between quantitative but also qualitative signs, methods of rank correlation are used (N.V.

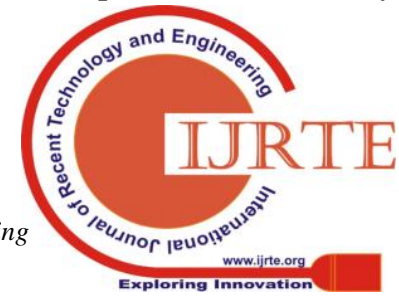


Pudova et al., 2004). Rank correlation is a measure of the relationship between random variables (observable signs, variables) when this relationship cannot be quantified using a normal correlation coefficient. The procedure for establishing a rank correlation is to streamline the studied objects in relation to a certain feature, i.e. they are assigned ordinal numbers - ranks (two numbers each according to two observed signs, between which the correlation is investigated). For example, the largest value for a variable is indicated by the number 1 , the second largest - by number 2 , and so on. (economic_mathematics.academic.ru/3765/ Rank_correlation)

\section{RESULTS}

As a result of a change in the gender and age structure of the population, structural changes have occurred in the population of Uzbekistan. As you know, the main source of supply in the labor market is labor resources, which in turn are formed from the number of people in working age. The dynamics of changes in the age composition of adolescents is described in Table. one.

Table 1. Dynamic, structural and age shifts in the population of Uzbekistan (in average annual terms) for 1991-2017

\begin{tabular}{|c|c|c|c|c|c|c|c|}
\hline Years & $\begin{array}{c}\text { Average annual } \\
\text { population } \\
\text { (thousand people) }\end{array}$ & $\begin{array}{c}\text { Oounger } \\
\text { than able- } \\
\text { bodied }\end{array}$ & \% & $\begin{array}{c}\text { Out of the total population in the age } \\
\text { in working } \\
\text { capacity }\end{array}$ & \% & $\begin{array}{c}\text { older than the } \\
\text { able-bodied }\end{array}$ & $\%$ \\
\hline $1991-1995$ & 21573,9 & 9299,3 & 43,1 & 10605,7 & 49,2 & 1672,4 & 7,7 \\
\hline $1996-2000$ & 23730,1 & 9921,3 & 41,8 & 12021,0 & 50,6 & 1787,8 & 7,6 \\
\hline $2001-2005$ & 25417,1 & 9595,2 & 37,7 & 13998,2 & 55,1 & 1823,7 & 7,2 \\
\hline $2006-2010$ & 27116,7 & 9065,8 & 33,4 & 16100,9 & 59,4 & 1950,0 & 7,2 \\
\hline $2011-2017$ & 30260,8 & 9117,9 & 30,8 & 18489,0 & 60,1 & 2453,9 & 8,1 \\
\hline
\end{tabular}

Analyzing the data in table 1 . it can be noted that the proportion of the population younger than working age steadily decreases from $43.1 \%$ in $1991-1995$. up to $30.8 \%$ in 2011-2017. In 2011-2017, compared with the initial period of independence of the country (1991-1995), their number decreased by $2.0 \%$ or decreased by 12.7 , and the absolute number - by 18.6 thousand people. This is due to a sharp decline in the birth rate. From 1991-2017, the birth rate decreased by 1.5 times and in 2017 was 23.5 born per thousand people, against 35.1 in 1991.

This is also explained by the fact that the population of the republic is moving to a new type of fertility, characterized by its lower coefficients, concentration of births in young age groups, a decrease in the average age of the mother at birth and an increase in the proportion of children of low birth order.

The growth in the working-age population was steady and increased throughout the period under consideration. This process is associated with the entry of a large number of people born in 1980-1990 (when high birth rates were observed - at least $35 \mathrm{ppm}$ ). The average annual absolute increase in the number of working age was 315.3 thousand people, and the average annual growth rate of $1.1 \%$.

All the observed trends in the dynamics of the number and structure of the working-age population (whose proportion in the total population increased from $49.2 \%$ to $61.5 \%$ in 2011-2017) indicate an increase in the number of people older than the working age (population aging) in perspective. The share of the population over working age varies slightly, being approximately at the same level (7.2-7.6\%). Their annual average absolute increase was about 31 thousand people, and the average annual growth rate was $0.8 \%$. In 1991-1997, there was a steady increase in the number of able-bodied pensioners in the country, more than 140-150 thousand pensioners entered the labor market (2000-2010). In subsequent years, the number of working pensioners gradually decreases. So, over the past 7 years, the average number of working pensioners was 95-100 thousand people, the average annual absolute decrease in their number was 4.2 thousand people (from 2019, with the adoption of the resolution on paying $100 \%$ of pensions to working pensioners, their number is likely to increase).

As mentioned above, the change in the demographic situation and the change in the number of labor resources is caused, above all, by a natural increase, a mechanical increase and levels of marriage and divorce.

After analyzing the dynamics of the number and age composition of the population, we proceed to the analysis of labor resources and the number of the employed population. The movement of labor resources implies a change in their number occurring naturally, i.e. due to entry into working age, exit from it and due to migration of working age population.

The reproduction of labor resources is also characterized by indicators of substitution (reproduction) and indicators of the demographic load (see Table 2). Replacement rates of labor resources can be calculated taking into account the influence of migration processes or without migration, they show the degree of quantitative renewal of labor resources. When the coefficient is less than 1, the labor resources in a country or region are not fully updated and this is called restricted reproduction. In the event that the coefficient is 1 , then this is a simple reproduction of labor resources. In case of exceeding the coefficient 1 , then in this case it is possible to note the expanded reproduction of the population. In reality, there is no country where the migration turnover outside the country does not affect the reproduction of labor resources and the entire population. But at the same time, the calculation of the coefficient from the point of view of studying the influence of only natural movement of population on the reproduction of labor resources without taking into account migration is also appropriate. In this case, only the number of births (with a 16-year lag) and deceased is taken into account. The advantage of this analysis is relative simplicity, as well as the possibility of a more accurate forecast of the number of labor resources. Since the migration processes are very difficult to predict with high accuracy. The calculated replacement rates are given in Table. 2

Table 2. Dynamics of indicators of working age for 1991-2015.

\begin{tabular}{|c|c|c|c|c|c|}
\hline \multirow{2}{*}{ Years } & \multicolumn{2}{|c|}{$\begin{array}{c}\text { The number included in the } \\
\text { working age (thousand } \\
\text { people) }\end{array}$} & $\begin{array}{c}\text { Численность вышедших } \\
\text { из трудоспособного } \\
\text { возраста (тыс. чел.) }\end{array}$ & $\begin{array}{c}\text { Migration } \\
\text { Substitution Ratio } \\
\text { (in times) }\end{array}$ \\
\cline { 2 - 5 } & $\begin{array}{c}\text { in just 5 } \\
\text { years }\end{array}$ & $\begin{array}{c}\text { onerage } \\
\text { per year }\end{array}$ & $\begin{array}{c}\text { In just 5 } \\
\text { years }\end{array}$ & $\begin{array}{c}\text { On average } \\
\text { per year }\end{array}$ & \\
\hline $1991-1995$ & 2284 & 457 & 556 & 111 & 4,1 \\
\hline $1996-2000$ & 2947 & 589 & 514 & 103 & 5,7 \\
\hline $2001-2005$ & 3136 & 627 & 493 & 99 & 6,3 \\
\hline $2006-2010$ & 3236 & 647 & 683 & 137 & 4,7 \\
\hline $2011-2015$ & 2918 & 584 & 1052 & 210 & 2,8 \\
\hline
\end{tabular}

Source: Stat collection of the Republic of Uzbekistan, 2018 
As can be seen from the data in the table, the labor replacement ratio tends to increase. During the analyzed period, this indicator exceeded one several times: from 2.8 to 6.3 times. The highest degree of reimbursement of labor resources falls on 2001-2005, amounting to 6.3 times. During this period, an average of 627 thousand people enter the working age annually.

However, starting from 2006, the ratio began to decline and 2011-2015. he was equal to 2.8 times. This fact of decline has its explanation. In the early 1990s, generations born in the mid-1970s (when the total fertility rate exceeded 6.49 births per woman) entered the working age, and at the beginning of the new century, the generation born in the late 1990s (when total fertility rate did not exceed 2.8 births per woman).

Features of the age composition of the population affect the economic situation of the family and the region as a whole, depending on how many people of working age are accounted for by one "breadwinner". The quantitative ratio of the three main age groups is of great importance for the economy of a country or its individual region. As an indicator of the security of society with labor resources, the specific weights of each of these three integrated age groups of the population and the so-called demographic load of labor resources, i.e. the number of persons outside the working age per 100 people of working age.

Let us trace the influence of the age structure on the change in the "demographic load" - the ratio of the population in the age younger and older than the working age to the number of people in the working age, table. 3

Based on the analysis of the data in Table 3, the following can be noted:

- during the analyzed period, the load of children was higher than the load of the elderly (more than 5 times). However, due to the decline in the birth rate in recent years, the load of children has steadily decreased. In 2011-2015 compared to 1991-1995. its decline was 37 percentage points;

- the load factor of older people varies at about the same level, although it has decreased from $15 \%$ to $12 \%$ compared to the beginning of the analyzed period, and has increased significantly since 2010 , therefore, there is no acute problem of population aging;

- the dynamics of the total demographic load has a pronounced tendency to decrease compared with the beginning of the analyzed period, it decreased from 99 to 62 people. The highest value of the demographic load in 1991-1995 - 99 people per 100 people. working age population; the lowest - in 2011-2015. - 62 people;

Table 3. The dynamics of the demographic load coefficients of the Republic of Uzbekistan for 1991-2015

\begin{tabular}{|r|c|c|c|c|c|c|}
\hline \multirow{2}{*}{ Year } & \multicolumn{2}{|c|}{$\begin{array}{c}\text { Average annual population } \\
\text { outside the working age }\end{array}$} & \multicolumn{4}{|c|}{ Including the average number } \\
\cline { 3 - 7 } & $\begin{array}{c}\text { Total } \\
\text { thousand } \\
\text { people. }\end{array}$ & $\begin{array}{c}\text { Per 100 people } \\
\text { of working age }\end{array}$ & $\begin{array}{c}\text { Total } \\
\text { thousan } \\
\text { age }\end{array}$ & $\begin{array}{c}\text { Per 100 people } \\
\text { of working age } \\
\text { people }\end{array}$ & $\begin{array}{c}\text { Total } \\
\text { thousa } \\
\text { nd } \\
\text { people }\end{array}$ & $\begin{array}{c}\text { Per 100 people } \\
\text { of working age }\end{array}$ \\
\hline $1991-1995$ & 10971,7 & 99 & 9299,3 & 84 & 1672,4 & 15 \\
\hline $1996-2000$ & 11709,1 & 98 & 9921,3 & 83 & 1787,8 & 15 \\
\hline $2001-2005$ & 11418,9 & 82 & 9595,2 & 69 & 1823,7 & 13 \\
\hline $2006-2010$ & 11015,8 & 68 & 9065,8 & 56 & 1950,0 & 12 \\
\hline $2011-2015$ & 11564,6 & 62 & 9117,9 & 49 & 2446,7 & 13 \\
\hline Source: Stat collection of the Republic of Uzbekistan, 2018 \\
- the indicator of the total demographic load in the
\end{tabular}

republic in 1991-2015 is reduced, and the reduction is due to a decrease in the magnitude of the load coefficients for replacing children (Fig. 1).

- for the structure of the population of the Republic, a higher proportion of people younger than working age is characteristic.

- for each age group, the problems of adaptation to new living conditions have their own generational characteristics: different tensions on the labor market for people of working age, different demographic burdens of dependents and, as a result, different per capita incomes and standard of living, different needs in receiving pensions, benefits, etc.

Prospects for filling labor resources in a country in which a relatively high proportion of pensioners will be less favorable than in a country with the same demographic burden, but a high proportion of children and adolescents. Thus, we can't attribute the total demographic burden of the population of modern Uzbekistan to a uniquely progressive type, since the load of children decreases, and the structure of the population, in which the proportion of young and child population decreases, is unfavorable, as the further development of labor resources depends on the number people who enter working age. The absolute increase in the economically active population is provided by young people who are in working age.

The main problem of labor resources is the provision of employment and their effective use, which ensures the economic growth of Uzbekistan and, as a consequence, the improvement of the quality and growth of the standard of living of the population.

\section{Conclusion.}

A study of the interaction of demographic processes in the labor market revealed the following problems and challenges:

- the birth rate is gradually decreasing, which in the future will affect the number of labor resources;

- the demographic load on the part of pensioners is increasing, which in turn will put pressure on the country's pension system;

- the share of labor resources is reduced, which may adversely affect the growth rate of the economy.

To stimulate fertility, it is necessary to introduce additional social benefits (take into account the entire period of the decree in the work experience when paying pensions) for all mothers employed in caring for children under 3 years old. It is necessary to gradually increase the retirement age to 65 years for both men and women. Since the average duration of women is longer than men and the experience of developed countries shows the need for gender equality, the retirement time should be equalized for both sexes.

To compensate for the reduction in the share of labor resources, it is necessary to attract migrant workers who have left. To do this, increase the share of high value-added production, which will increase the average wage in the country. 


\section{REFERENCES}

1. Sh.M. Mirziyoev (2018) "Message of the President of the Republic of Uzbekistan to the Parliament" 12.28.2018

2. Presidential Decree of 22.01.2018. "On the State Program for the Implementation of the Action Strategy for the Five Priority Development Areas of the Republic of Uzbekistan in 2017-2021 in the "Year of Support for Active Entrepreneurship, Innovative Ideas and Technologies. http://www.ombudsman.uz/ru/press_center

3. Law "On Employment" (1998) http://lex.uz/docs/9878

4. Sh.M. Mirziyoyev (2017) Report of the President of the Republic of Uzbekistan at the 72nd session of the United Nations General Assembly $\begin{array}{lll}\text { September } & 19, & 2017\end{array}$ http://www.uza.uz/ru/politics/prezident-uzbekistana-shavkat-mirziyeevvystupil-na-72-y-ses-20-09-2017

5. Statistical compilation (2018): Social development and standard of living in Uzbekistan. Tashkent 2018.

6. Statistical compilation of the Republic of Uzbekistan (2017). - Tashkent 2018.

7. Abdurakhmanov K., Zokirova N (2013). Labour economics and sociology. Tutorial. Jakarta-2013. p. 428

8. Abdurakhmanov K.Kh. (2018) Demographic Processes in Uzbekistan: Challenges and Prospects. Scientific achievement of third millennium. Collection of Scientific paper on material VIII Inretnational scientific conference. 30.09.2018. Part 2. Los Angeles 2018

9. Abdurakhmanova G., Kuchkarov G. (2018) Strategy for ensuring decent work for youth in the Republic of Uzbekistan. Norwegian journal of development of the international science. № 25/2018. Vol.3

10. M. Nazrul Hoque, Mary A. McGehee, Beverly Pecotte Applied Demography and Public Health in the 21st Century Springer International Publishing Switzerland 2017

11. Demand for Labor. Daniel S. Hamermesh. United States of America by Oxford University press 2017

12. John F. May World population policies. Springer Science + Business media B.V. 2012

13. Стешенко В.С. (2014) О содержании понятий "демографическое развитие" и "человеческое развитие" тождества и различия http://www.demoscope.ru/weekly/2014/0583/nauka04.php\#_ftn1

14. Ewa Zofia Frątczak (2013) Demographic processes: past, present and future - selected issues PAPERS on GLOBAL CHANGE, 20, 63-84, 2013

15. Odegov Yu.G., Rudenko G.G. Labor Economics 2nd ed. per. and add. Textbook and workshop for academic undergraduate. M .: Publishing house "Urayt", 2014, 2015. 423 p.Roland Pressat (1978) Statistical Demography University Press Cambridge 1978 p.80

16. Labor Market (2003): Textbook. / Ed. Prof. Vs Bulanova and prof. N.A Volgina-2nd ed., Pererab. and add. - M .: Izd-vo "exam", 2015.- p.39/ 480p.

17. Rofe A.I. (2016) Labor Market: textbook / A.I. Rofe.-M.KRONUS, 2016.s. 10-272s

18. The labor market and incomes (1999) ./ Ed. ON. Volgin. Tutorial. - M .: Information and publishing house "Filin", 1999. - $280 \mathrm{p}$.

19. Nikolaev, I.N. (2006) Economics in questions and answers: studies, manual. - M .: TK Velbi, Prospect Publishing House, 2006 - 336 p.

20. Zemyonukhina S.G. (2004) Labor market in the system of reproduction of human resources: general and specific. "Labor market, employment, income: problems and development trends (training of specialists in the labor market and employment)". Proceedings of the international scientific-practical conference on April 25-27, 2004. P.46

21. Kashepov A.V., Sulakshin S.S., Malchinov A.S. (2008) Labor Market: Problems and Solutions. Monograph. - M .: Scientific expert, 2008. - 232 p.

22. Labor economics. (2002) Current state, problems and development trends: Monograph / ed. S.N. Trunina, I.V. Gelety, N.R. Molochnikov. Krasnodar: KubSU publishing house. 2002. P.112-113

23. Vinokurov, MA (1981) Manpower resources of the region and the labor market (on the example of the Irkutsk region). Irkutsk, 1981, p.14 Economic Theory (1999). Textbook. Abdurakhmanov K.Kh. and others. T. "Shark", 1999, 358.

24. Pudova N.V., Nikitin V.V. (2004) Analysis of the values of the Spearman's rank correlation coefficient Economic analysis: theory and practice No. 3.- 2004

25. Smith A. (2016) Research on the nature and causes of the wealth of nations. M .: Eksmo, 2016. 